\title{
POSITIVE AND NEGATIVE CHARACTERISTICS OF THE WESTERN THEORIES FOR MOVEMENT LEARNING
}

\author{
Boyanka Peneva, Vladimir Chernev, Ljubomir Borisov
}

\begin{abstract}
Summary
Human knowledge is in a process of a constant development. Nowadays in the scientific space two tendencies can be seen. Firstly, theory and practice are in a constant contradiction. The existing theories do not correspond to the new data from the practice and the experience. Secondly, in the age of the enormous information due to the new electronic technologies scientists can come in a touch with the concepts of their colleagues dealing with the same problems in the scientific space but living thousands kilometers away from them. New ideas emerge on the base of the exchanged information. Comparisons can be done and are done. In the sphere of movement learning worldwide three main tracks are outlined.

- Western theories - written mainly in English.

- Eastern theories of Russia (the former Soviet Union countries) and the former socialist countries - written mainly in Russian.

- Eastern theories of Tibet, China, Japan, etc. whose knowledge in the sphere of movement learning as a whole is still not well overspread in the Western world.

Our study is with address the Western theories for movement learning whose pick nowadays are supposed to be (1) The schema-theory of Richard A. Schmidt (1975) \& (2) The movement notation principles of Rudolf Laban (1956).
\end{abstract}

Key Words: movement learning, schema theory, variability in motor skill education

\section{Introduction}

Movement learning is of interest to people from the dawn of humanity. In the times of globalization and high level of information spreading all over the world, scientists of different spheres fall in the situation (1) to pick out new data, standpoints, ideas, etc. (2) to compare the different views and to outline the knowledge on a higher level. With the spreading of Internet and the predominant use of the English language in its publications in front of the specialists in the field of physical education of children arise the opportunity to get acquainted with the work in movement learning of their colleagues in other countries, with the different theories that exist in this field as well.

\section{Methods}

In the study are used the following methods:

- Research on scientific literature - Internet information is used too.

- Comparative analyses

- Generalization

\section{Results}

Purpose of the study is to reveal the positive and the negative characteristics of the most known and recognized Western theories for movement education. On this base a comparison to be done with the theories in this attitude that are in use in Bulgaria.

Still in 1956, Rudolf Laban formulated on the base of his experience in dance teaching the movement notation principles (R. Laban, 1956).

1. Awareness of body

2. Awareness of space - space harmony

3. Awareness of effort

4. Relationships

Unfortunately, these principles for a long time remained unknown for the physical education and sports specialists in Bulgaria.

The retrospective analysis of the Western theories for movement education shows that their aim is to reach highest accession to the functions of the motor control mechanisms. The assumption is that the clearness of this problem will lead to effectiveness in the rule of movements and higher results in the methods of education. Regardless of the schematic representation of the views in these theories, the Western authors reach to the idea for variability of practice in motor skill education. 
Four main theories for movement education are more famous in the Western scientific space. With the advance of insight of matters, betterment of the comprehension on the problem is established.

(A) The theory of E.C. Poulton - the year is 1957 (T. McMorris, 2004)

(B) The memory-drum theory of Henry \& Rogers from 1960 (J. G. Anson, 1982).

(C) The closed-loop theory of motor learning of Jack A. Adams from 1971 (J.A. Adams, 1971, 1976, 1987).

(D) The schema-theory of Richard A. Schmidt - the year is 1975 (R. A. Schmidt, 1975).

The theory of E. C. Poulton (1957) is characterized with the use for the first time of the terms closed and opened in the skill acquisition. In it it is is spoken about opened skills and closed skills.

The memory-drum theory of Henry \& Rogers (1960) presumes response of the memory to every movement. This theory is the first one that explains the mechanism for motor implementation with central stored inborn programmes. According to Henry \& Rogers every movement demands its own motor programme. Here can be seen the imperfection of this theory. Own motor programme for every movement predicates enormous capacity for storage as the person can move his muscles in many ways. Such enormous capacity is not available and then comes the question "Maybe the mental notion of the movements is organized in more economic way" (J. G. Ansons, 1982).

The closed-loop theory of motor learning of Jack Adams (1971) is precondition for the nascency of the schema-theory of Richard Schmidt. This is the theory that nowadays dominates in the Western countries (Germany, USA, France, Canada, etc.). It is accepted that this theory most correctly explains the mechanism for motor skill acquisition.

Let us say some more words about the closed-loop theory of Jack Adams. Helfried Albrecht \& Klaus Fischer (1988) in their article "The contribution of schema theory of motor learning to research in motor performance" (1988) connect the nascency of Jack Adams theory as a result of the influence of cybernetics. In the same time, they define thid theory as concurrent to the theories of Nikolai Aleksandrovich Bernstein (1896-1966) and Peter Kuzmich Anohin (1898-1974). The following remarks may be done here:

1. The theory of Nikolai Aleksandrovich Bernstein is published in 1947.

2. Even in these early times though slighgtly slower than today good and correct knowledge is spread in the world for better realization in the practice.

According to the closed-loop theory for skill acquisition (1) memory trace selects and initiates given movement plan, (2) perceptual trace compares movement in progress with correct memory of the movement, (3) practice reduces the error.

The closed-loop theory has some deficiencies. The main disadvantages are that it (1) requires feedback, (2) more feedback does not always improve performance, (3) is difficult to be applied to complex movements. Jack Adams built his theory on the base of the slow movements and this reduces its validity. However, Jack Adams'closed-loop theory is an important leap forward in movement learning research.

The schema-theory of Richard A. Schmidt (1975) suggests in opposition to closed-loop theories that a motor programme contains general rules to be used to different environments or situational content via the involvement of open-loop control process and generalized motor programme (GMP). So, when learning novel movements an individual may generate a new GMP based on the selection of parameters or refine an existing GMP (reducing the storage problem that exists in the closed-loop theories), depending on prior experience with movement and task content. The GMP is thought to contain an abstract representation for a class of movements with invariant features pertaining to the order of events (R. A. Schmidt \& T. D. Lee, 2005).

According to R. A. Schmidt, four things are stored in memory after an individual generates a GMP.

1. The initial conditions of the movement, such as the proprioceptive information of the body.

2. The response specifications for the motor programme (the parameters used in the GMP, such as speed and force).

3. The sensory consequences of the response, which contains information about the movement felt/looked.

4. The outcome of that movement, which contains information of the actual outcome of the movement with knowledge of results. 
All this information is stored in components of the motor response schema, which includes the recall schema and recognition schema. Throughout a movement, the recognition schema is compared to the expected sensory information (proprioceptive and extroceptive) from the ongoing movement to evaluate the efficiency of the response.

The Richard Schmidt's schema theory illustrates that movement learning consists of continuous processes that update the recall and recognition schemas with each movement that is done (R. A. Schmidt, 2003).

In his research work Richard Schmidt pays great attention to the variability of practice as hypothesis. "The hypothesis claims that variable practice is more effective for schema development than constant practice. The empirical foundation of the variability prediction is evaluated on the basis of 63 relevant studies (mainly journal articles and dissertations), reporting 73 different experiments and covering 12 years of empirical research (from 1975 through 1987) (J.H. Van Rossum, 1990).

The variability of practice is position affirmed by Nikolai A. Bernstein in 1947 (Н.А. Бернштейн, 1947), later introduced in Bulgaria by М. Бъчваров/М. Bachvarov in 1982 as diversity of the specialized training (М. Бъчваров, 1982).

\section{Conclusions}

The Western and the Eastern specialists (Russia / the former Soviet Union countries and the former socialist countries) in physical education and sports since the 40-ies of XX century have done observations and conclusion in the sphere of movement education and the acquisitions of motor skills. As the truth is one the two streams in their independent way reached to the conception about the variability of practice in motor skill education.

In the Western theories prevails the schematic representation.

\section{References}

БЕРНШТЕЙН, Н.А. О построении движения, М., 1947 Ново издание на руски език през 2012 г./New edition in Russian in 2012 - ISBN978-5-458-24996-6 БъЧВАРОВ, М. Разнообразие на специализираната тренировка”, С., „Медицина и физкултура”, 1982. (in Bulgarian)

ADAMS, J. A. (1971) A closed-loop theory of motor learning. Journal of Motor Behaviour, v.3, 111-149.

ADAMS, J.A. (1976) Issues for a closed-loop theory of motor learning. In G. L. Stelmach (Ed.) Motor control: Issues and trends, New York, Academic Press.

ADAMS, J.A. (1987) Historical Review and Appraisal of Research on the Learning, Retention, and Transfer of Human Motor Skills, Psychological Bulletin, Vol. 101, $\mathrm{N} 1,41-74$.

ALBRECHT, H., \& FISHER, K. The Contribution of SchemaTheory of Motor Learning to Research in Motor Performance, "International Journal of Physical Education", 3, 1988.

ANSON, J.G. (1982) Memory drum theory: alternative tests and explanations for the complexity effects on simple reaction time, Journal of Motor Behaviour, Sep. 14 (3):228-246.

BERNSTEIN, N. (1967) The Coordination and Regulation of Movements, Oxford, Pergamon.

LABAN, R. (1956) Principles of Dance \& Movement Notation, London.

McMORRIS, T. (2004) Acquisition \& Performance of Sports Skills, John Wiley \& Sons Ltd., Atrium, Southern Gate, Chichester, West Sussex PO 19, England.

SCHMIDT, R.A. (1975) A schema theory of discrete motor-skill learning, Psychological review 1975, 82, 225260.

SCHMIDT, R.A. (2003) Motor schema theory after 27 years: Reflections and implications for a new theory. Research Quarterly for Exercise and Sport, 74, 366-375.

SCHMIDT, R.A. \& LEE, TIMOTHY DONALD (2005)

Motor control and learning: a behavioral emphasis, Champaign, IL: Human Kinetics. ISBN978-0-73604258-1. OCLC265658315.

VAN ROSSUM, J.H. Schmidt's schema theory: the empirical base of the variability of practice hypothesis: A critical analysis, Human Movement Science, Volume 9, Issue 3-5, September 1990, Pages 387-435. 